\title{
Behavior of Lateral Resistance of Flexible Piles in Layered Soils
}

\author{
${ }^{1}$ B.S.Chawhan, ${ }^{2}$ S.S.Quadri, ${ }^{3}$ P.G.Rakaraddi, \\ ${ }^{1}$ Asst. Prof, Govt. Engineering College, Haveri-581110, \\ ${ }^{2}$ Prof.and Head, BVBCET, Hubli-580031, \\ ${ }^{3}$ Associate Professor, BEC, Bagalkot,
}

\begin{abstract}
This paper presents an experimental investigation on the lateral load carrying capacity of model piles of different flexural stiffness embedded in loose sand between dense sand and dense sand between loose sand layered soil strata. Attempts has been made to study the variation of lateral stiffness, eccentricity and soil layer thickness ratio and the effect of various parameters on the magnitude of $N_{h}$. The result of a model tested for the piles embedded in IS grade-II dry Ennore sand under monotonic lateral loadings. Experimental results are used for the load-deflection curves ( $p-y$ curves) for laterally loaded piles. The proposed p-y curves were compared to the existing curves with $N_{h}$ and were evaluated with the experimental data. The ultimate lateral soil resistance and subgrade modulus were investigated and discussed.
\end{abstract}

Key Words: Subgrade modulus, flexural stiffness, ground line deflection, model tests, piles, soil-pile interaction.

\section{Introduction:}

Pile foundations are the most popular form of deep foundations used for both onshore and offshore structures. They are often used to transfer large loads from the superstructures into deeper, competent soil layers particularly when the structures is to be located on shallow, weak soil layers. Piles are frequently subjected to lateral forces and moments; for example, in quay and harbor structures, where horizontal forces are caused by the impact of ships during berthing and wave action; in offshore structures subjected to wind and wave action; in pile-supported earth retaining structures; in lock structures, in transmission-tower foundations, where high wind forces may act; and in structures constructed in earthquake areas such as Japan or the West Coast of the United States.

The ultimate capacity of flexible piles and small pile groups in homogeneous and layered sand has been reported by Meyerhof and Ghosh 1989. But the state of art does not indicate a definite methodology by which the values of $\mathrm{N}_{h}$ can be obtained. Most of the investigators agree that $\mathrm{N}_{h}$ depends on soil and pile properties and value decreases with the increase in lateral load. Palmer et.al. (1954) indicated that width of pile has an effect on deflection, pressure and moment along pile even when flexural stiffness (EI) of pile is kept constant. Murthy (1992) has developed some relationship between $\mathrm{N}_{\mathrm{h}}$ and other parameters like soil properties, flexural strength and lateral load. Dewaikar and Patil (2006) studied the analysis of laterally loaded pile in cohesionless soil and the Byung Tak Kim, Nak-Kyung Kim, Woo Jin Lee, and Young Su Kim studied the experimental Load Transfer Curves of Laterally Loaded Piles (April 2004).

This paper presents the experimental investigation of lateral load carrying capacity of model piles of various materials in homogeneous sand (both in loose and dense state), loose between dense and dense between loose sand layers with horizontal loads acting at various eccentricities. In all the tests, the outer diameter (d) and depth of embedment (D) of piles are kept constant.

\section{Experimental Set-Up And Model Tests}

The test were carried in IS grade-II dry Ennore sand having placement density of $13.35 \mathrm{kN} / \mathrm{m}^{3}$ and $\Phi=31^{0}$ for loose soil condition and $15.89 \mathrm{kN} / \mathrm{m}^{3}, \Phi=39^{\circ}$ for dense condition. The tests were conducted in two steps. a) The soil condition is loose sand layer between dense sand layer with $\mathrm{H} / \mathrm{D}$ ratio of $0.25,0.50,0.75$, and 0.90 . b) The soil condition is dense sand layer between loose sand layer with $\mathrm{H} / \mathrm{D}$ ratio of $0.25,0.50,0.75$, and 0.90 , where $\mathrm{H}$ is the thickness of middle layer and $\mathrm{D}$ is the total depth of embedment of the pile $(=300 \mathrm{~mm})$. In both the cases the eccentricities of $0,50,100,150$ and $200 \mathrm{~mm}$ are conducted in homogeneous loose sand layer and dense sand layer. The outside diameters of the piles are $16 \mathrm{~mm}$ for solid Steel and Wooden Piles. Hollow Aluminium pile with $16 \mathrm{~mm}$ outside and $0.3 \mathrm{~mm}$ thickness. The embedment depths of all the piles are $300 \mathrm{~mm}$. The flexural rigidity of steel, wooden and Aluminium piles were $642.106 \mathrm{Nm}^{2}, 506.12 \mathrm{Nm}^{2}$ and $51.041 \mathrm{Nm}^{2}$ respectively. The relative stiffness factors for steel, wooden and Aluminium were $0.1192,0.939$ and 0.0094 respectively for Loose sand layer and 0.0263, 0.0207 and 0.0020 for Dense sand layer. The horizontal displacement and rotation of pile cap are recorded by L.V.D.T. and two dial gauges. The stabilized 'Rainfall-Technique' this standard technique is available in standard literature and this technique was used to pour the sand in the testing steel tank. Figure. 1 shows schematic sketch of experimental setup. 


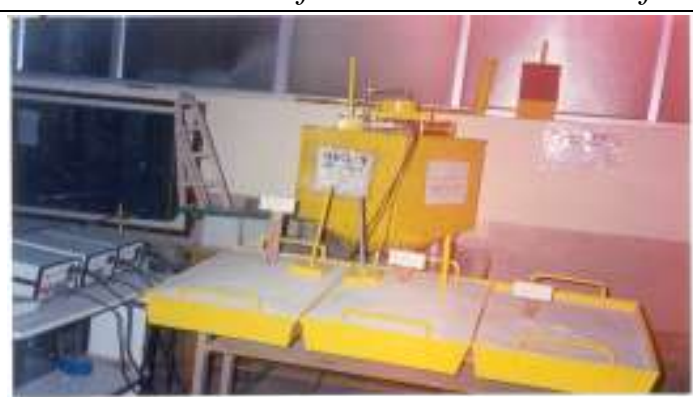

Fig.1 Schematic sketch of experimental setup

The ultimate load bearing capacity of model piles are obtained from load deflection curves by the following criteria.

(A). Single tangent method

(B). Double tangent method

(C). Load corresponding to ground line deflection equal to $10 \%$ pile diameter

(D).Load corresponding to ground line deflection equal to $20 \%$ pile diameter

(E). Log-Log method.

It is observed that different criteria yield different ultimate load (vide Table-1). For the present analysis, the average of first three criteria is taken as ultimate pile capacity.

\section{Method Of Analysis}

Reese and Matlock (1956) have developed a set of equations based on dimensional analysis for computing deflection, slope, moment etc, along the pile. These equations are very useful for predicting the nonlinear behavior of laterally loaded piles provided the magnitude of $\mathrm{N}_{h}$ is known at each load level. For deflection and slope of free head pile at ground level, the following equations are given by Reese and Matlock (1956).

$Y_{g}=\frac{2.435 P T^{3}}{E I}+\frac{1.62 M T^{2}}{E I}$
$S_{g}=\frac{1.62 P T^{2}}{E I}+\frac{1.75 M T}{E I}$

where, Relative Stiffness factor $T=\left(\frac{E I}{N_{h}}\right)^{\frac{1}{n+4}}$

$\mathrm{P}=$ Lateral load at pile head; $\mathrm{M}=$ Moment at pile head $(=\mathrm{P} * \mathrm{e})$; e=Eccentricity of horizontal load measured from ground level; and EI=Flexural stiffness of the model pile.

From the observed lateral resistance and corresponding ground line deflection and rotation, the value of coefficient of soil modulus variation $\mathrm{N}_{\mathrm{h}}$ is estimated for different types of model piles by using the above equations (1) and (2).

Murthy .V.N.S (1976) has proposed the equations for determining $N_{h}$ in cohesionless soil at each stage of loading as

$N_{h}=\frac{A}{P_{t}^{m}}$

where $\mathrm{P}_{\mathrm{t}}=$ Lateral load at pile head, $\mathrm{m}$ is a constant equal to 0.8 and $\mathrm{A}$ is a factor which is a function of the effective unit weight $\gamma$ of the soil and flexural stiffness EI of the pile.

$N_{h}=\frac{156 C_{f} \gamma^{1.5}(E I B)^{1 / 2}}{P_{t}}=\frac{A_{s}}{P}$

where, $\mathrm{P}_{\mathrm{t}}=$ Lateral load; $\mathrm{A}_{\mathrm{s}}=$ Constant for pile in sand; $\mathrm{P}=\mathrm{Pt}(1+0.67 \mathrm{e} / \mathrm{T})$; and $\mathrm{C}_{\mathrm{f}}=$ Correction factor for the angle of friction $=3^{*} 10^{-5}(1.315){ }^{\Phi}$, where $\Phi$ is in degrees.

\section{Results and Discussions}

The experimental results were carried out and tabulated in following Table- 1 and Table-2. 
Table-1 presents ultimate loads of model Aluminium piles (embedded in Dense between loose sand layer) estimated from observed load deflection curves using different criteria mentioned earlier. It can be noted that ultimate load of a pile is not unique but depends on different methods or criteria. Table-2 presents ultimate loads of different pile materials in Loose between Dense layers estimated from observed experimental values. It can be noted that ultimate lateral resistance of pile decreases with the increase of $\mathrm{H} / \mathrm{D}$ ratio in Loose between dense sand layer where as it increases with the increase of H/D ratio in Dense between Loose sand layer. Fig.2 shows typical load deflection curves of steel, wooden and aluminium piles embedded in loose sand between dense sand layer with $e=50 \mathrm{~mm}, \mathrm{H} / \mathrm{D}=0.25$. In fig. 3 the lateral load deflection curves of aluinium pile embedded in dense sand between loose sand layer having $\mathrm{H} / \mathrm{D}=0.9$ with varying eccentricity. The figure reveals that ultimate lateral resistance of pile decreases with increase in eccentricity. This phenomena is observed in all types of model piles irrespective of all condition (i.e loose sand layer, dense sand layer, loose sand layer between dense sand layer and dense sand layer between loose sand layer).

In fig.4 the variation of coefficient of soil modulus v/s flexural stiffness(EI) curve of three model piles in dense between loose sand layer having $\mathrm{h} / \mathrm{D}=0.90$ with varying eccentricity. The figure reveals that flexural stiffness of pile increases with increase in variation of coefficient of soil modulus. This phenomena is observed in all conditions of soil layers.

In fig.5 indicates the variation ultimate load of model piles with flexural stiffness EI when they are embedded in dense sand layer between loose sand layer having various $\mathrm{H} / \mathrm{D}$ ratio and $\mathrm{e}=50 \mathrm{~mm}$. this reveals that ultimate load increases with increase in flexural stiffness of pile when all other conditions are kept constant.

Table-1.Comparison of ultimate load (N) by various methods (Aluminium pile, $\mathrm{H} / \mathrm{D}=0.5$, Dense between loose sand layer).

\begin{tabular}{|l|l|l|l|l|l|}
\hline Eccentricity, e in mm & \multicolumn{5}{|l|}{ Methods } \\
(Different Criteria)
\end{tabular}

Table-2. Ultimate load (N) of different pile (Steel, Wooden, and Aluminium pile, $\mathrm{H} / \mathrm{D}=0.5$, Dense between Loose sand layer).

\begin{tabular}{|l|l|l|l|l|}
\hline $\begin{array}{l}\text { Eccentricity } \\
\text {, in } \mathrm{mm}\end{array}$ & $\mathrm{H} / \mathrm{D}$ & Steel & $\begin{array}{l}\text { Woode } \\
\mathrm{n}\end{array}$ & $\begin{array}{l}\text { Alum } \\
\text { inum }\end{array}$ \\
\hline 50 & 0.50 & 16.96 & 29.66 & 14.98 \\
\hline 100 & 0.50 & 13.04 & 22.82 & 11.52 \\
\hline 150 & 0.50 & 11.74 & 20.54 & 10.37 \\
\hline 200 & 0.50 & 10.43 & 18.25 & 9.22 \\
\hline
\end{tabular}




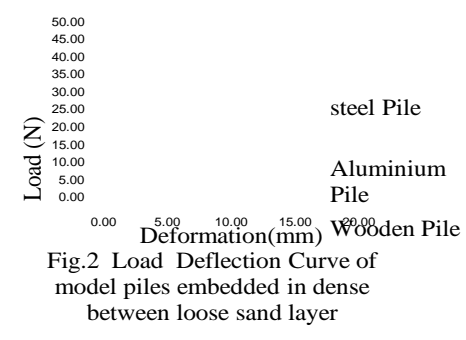

Dense sand layer between loose 100.89nd layer, $\mathrm{H} / \mathrm{D}=0.9$

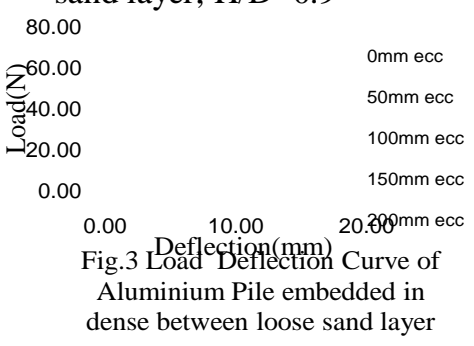

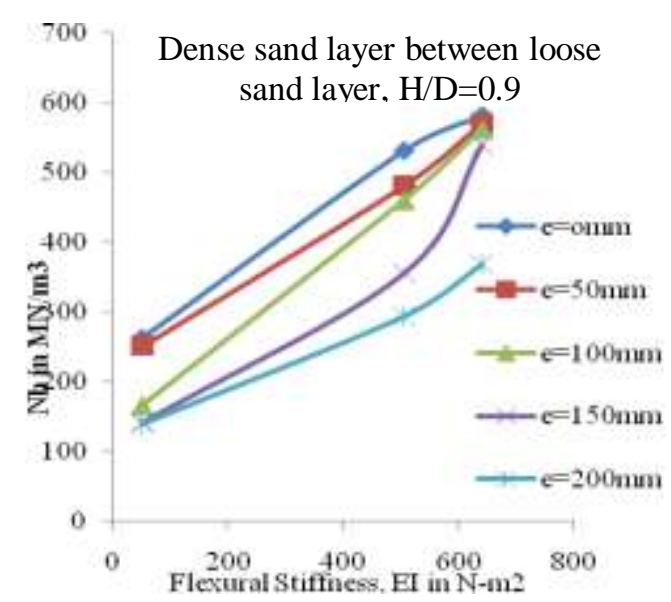

Fig.4. Variation of soil modulus $\mathrm{N}_{\mathrm{h}}$ with Flexural stiffness of piles embedded in dense between loose sand layer,

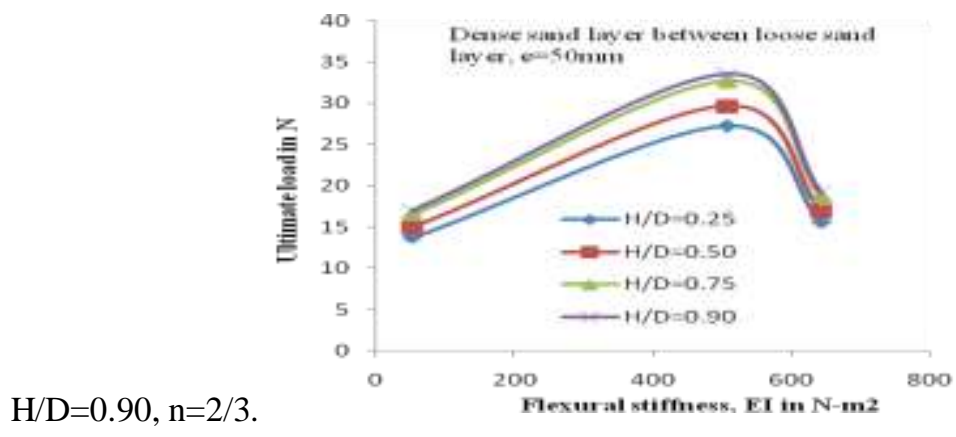

Fig.5. Variation of ultimate load with Flexural stiffness of piles embedded in dense between loose sand layer. 


\section{Conclusions}

The following conclusions are made based on the experimental investigations.

(i) The ultimate lateral resistance of single pile decreases with the increase in eccentricity of load, it is about 8 to $11 \%$.

(ii) The ultimate resistance of single pile subjected to horizontal load decreases with increase in eccentricity of load on the same pile provided the depth of embedment remains constant for homogeneous loose and dense layers, also loose between dense and dense between loose layered soils, and it is about 10 to $12 \%$.

(iii) The ultimate lateral resistance of pile increases with increased value of flexural stiffness of pile and it is about 8 to $13 \%$ and the magnitude of $\mathrm{N}_{\mathrm{h}}$ decreases with the increase in magnitude of horizontal load irrespective of flexural stiffness of pile and soil condition.

(iv) In dense sand, the magnitude of $\mathrm{N}_{\mathrm{h}}$ increases with the increase in value of flexural stiffness of pile where as in case of loose sand the value decreases with the increase in EI value of piles and the ultimate lateral load carried is more (10 to $12 \%$ ) in dense between loose sand layer and vice versa.

The tests may be conducted in multiple layers of Loose sand layer and Dense sand layer with constant and variable thickness of layers and also the Variation of Coefficient of soil modulus $\left(\mathrm{N}_{\mathrm{h}}\right)$ in a different soil layers along the depth can be studied.

\section{References}

[1]. Byung Tak Kim, nak-Kyung Kim, Woo Jin, Lee

[2]. and Young Su Kim. (2004), Experimental Load- Transfer Curves of Laterally Loaded Piles In Nak-Dong River Sand, Journal of Geotechnical and Geoenvironmental Engineering, 130(4),416-425.

[3]. Dewaikar D.M and Patil P.A. (2006), Analysis of a Laterally Loaded Pile in Cohesionless Soil, IGC 2006,14-16 December 2006, Chennai, INDIA, 467-4.

[4]. Dewaikar D.M and Patil, D.S.(2001), Behaviour of laterally loaded piles in cohesion-less soil under oneway cyclic loading, The New Millennium Conference, 14-16 December-2001.

[5]. Ghosh,D.P and Meyerhof,G.G.(1989), The ultimate bearing capacity of flexible piles in layered sand under eccentric and inclined loads, Indian Geotech.J,(19)3, 187-201.

Murthy.V.N.S. (1992), Nonlinear Behaviour of Piles Subjected to Static Lateral Loading.

[6]. P.Bandopadhyay and. B.C.Chattopadhyay. (1989), Ultimate Lateral Resistance of Vertical Piles, (2)4, 165-168.

[7]. Rees.L.C and Metlock.H. (1956), Non-dimensional solutions proportional to depth, Prooceedings $8^{\text {th }}$ Texas conference on Soil Mechanics and Foundation Engineering, Special publication no.29, Bureau of Engineering Research, University of Texas, Austin.

[8]. Terzaghi.K.(1955), Evaluation of coeeficient of subgrade reaction, Geotechnique, (5)4, 297-326. 